\title{
Spatial Analysis in Archaeology: Moving into New Territories
}

\author{
Philip Verhagen
}

\begin{abstract}
GIS has become an indispensable tool for archaeologists to organize, explore and analyse spatial data. In this introductory chapter, an historical overview of the development of GIS use in archaeology is given. It focuses on three major fields of application: site location analysis, modelling movement and transport and visibility analysis. This state of the art is illustrated by discussing three different case studies. Finally, some thoughts on the future of GIS in archaeology are presented.
\end{abstract}

\section{Keywords}

GIS • Archaeological theory $\bullet$ Site location analysis $\bullet$ Least-cost paths • Viewsheds

\subsection{Introduction}

It is now over 30 years ago that the term GIS was introduced in archaeology (Hasenstab 1983), and it is hard to imagine how archaeologists have ever done research without it. GIS and spatial analysis are now seen by most archaeologists as essential tools to explore, analyse and interpret spatial data and have become standard ingredients in many archaeological research projects. GIS and spatial analysis are

P. Verhagen $(\bowtie)$

Faculty of Humanities, Vrije Universiteit Amsterdam, Amsterdam, The Netherlands

e-mail: j.w.h.p.verhagen@vu.nl

extremely convenient techniques for more efficiently carrying out 'traditional' archaeological research. However, there are also those who maintain that the 'spatial turn', boosted by GIS technology, points the way to applying fundamentally different theoretical perspectives in archaeology.

In this chapter, I will give a condensed overview of the current state of GIS use in archaeology and attempt to sketch the current role of GIS and spatial analysis for archaeological interpretation and show its potential for changing theoretical perspectives and research traditions, drawing on examples from recent research. And lastly, I will try to look into the crystal ball and set a tentative agenda for future research. 


\subsection{The Position of GIS in Archaeological Research}

If we would have to describe the history of the use of GIS in archaeology in a nutshell, it could be summarized as a cycle of initial enthusiasm and proliferation in the 1980s and early 1990s, followed by severe criticism and (partial) disillusionment in the late 1990s, only to be reappraised again and rapidly gaining momentum in the late 2000s, leading to its current status as an almost indispensable research tool-or rather methodology-for dealing with spatial archaeological data. The main trends in this development have been described by, e.g. Kvamme (1999), Verhagen (2007: 13-25), McCoy and Ladefoged (2009), Wagtendonk et al. (2009) and Verhagen (2012) and need not be repeated here. However, when reading the academic literature on the subject (which has the tendency of being a rather slow detector of longer-term trends), we could be under the impression that archaeologists are still reluctant and hesitant in their appreciation and adoption of GIS-based spatial analysis. This is because of its association with the theoretical school of processual archaeology, with its underlying, naive support of scientism, and with its emphasis on environmental determinism (see Hacıüzzeller 2012). Theoretically oriented archaeologists were seriously concerned about these issues in the 1990s and early 2000s when thinking about how to deal with digital technologies in general. However, archaeological practice has certainly moved on since then, and currently archaeologists have generally embraced geographical database management, digital cartography and spatial analysis, if only for reasons of efficiency. To a lesser extent, they have also gradually adopted computer-based modelling as a research tool, although acceptance here has been a lot slower, due to the fact that it has stood in the middle of the processual versus post-processual controversy (see also Verhagen and Whitley 2012). This is part of a larger debate about computing applications in archaeology that has been described as an 'anxiety discourse' by Huggett (2013) and which is a general characteristic of emerging fields trying to establish their scientific identity.

One of the reasons why the debate on GIS has been quite tense is highlighted by Hacıgüzeller (2012). She distinguishes between two views of understanding the past, the representational and non-representational. In the representational view, the past is supposed to have an objective reality. This is a reality, however, that we cannot touch. For this reason we can only use representations to understand the past. This leads to a dualistic approach to research, separating, e.g. past and present and material and meaning. It also implies that there is a constant search for the right medium to construct representations that are as faithful to 'reality' as possible-and this is exactly where GIS filled a huge gap when it came to the scene in the 1980s. Digital cartography suddenly allowed researchers (not just in archaeology) to take mapping to a much higher level and to collect and manipulate geographical data in a much more sophisticated way.

The critique of this representational viewpoint is very prominent in the post-processual rejection of 'processualist' methods such as GIS (Thomas 1993, 2001, 2004; Tilley 2004, 2008). The preoccupation of post-processual researchers with bodily understanding as the preferred way to study the past, and in this way to come closer to the mindset of human beings long dead, shows that they were looking for new ways of representation, albeit in a different form than what cartography and other techniques of data complexity reduction could achieve (see, e.g. Tilley 2004). It has however been noted before (Fleming 2006; Verhagen and Whitley 2012) that the rejection of the 'scientific method' by post-processualism contradicts one of its own tenets, i.e. the exploration of multiple and equivalent views of the past. As such, 'scientific' approaches can and should have their place in archaeological research practice, and the predominance given to narrative by post-processualists is not necessarily the best way to represent the past either.

What the early practitioners of GIS and their critics did not perceive is that GIS and other 
computer-based methods enable pluralism, rather than enforce reductionism. Using these tools, a multitude of representations can be created with little effort, in which there is no longer an easy way to distinguish between right and wrong and between more and less plausible. Because of this, cartography has been effectively democratized, and mapping these days is, more than ever, an exercise in (scientific) rhetoric.

Following Hacıgüzeller's (2012) view, we can gain much more by adopting a nonrepresentational approach to the study of the past, and thus to GIS. In this view, the past is not something that can be understood in a static and definitive way, but rather something that continually changes and is repeatedly reconstructed in the present. It is therefore a plea for eclecticism in using GIS and to consider it more as a constantly changing research practice than as a technology-driven instant solution that can be applied to all forms of spatial data and all archaeological research questions. It also follows that GIS-based spatial analysis and modelling can never be a stand-alone approach, but should be an integral part of what we might call 'hybrid' archaeological research-which of course echoes the strong call for interdisciplinarity in modern science.

We might even go one step further and ask ourselves whether spatial analysis and modelling could not be just one of many approaches, but perhaps constitute a leitmotiv for doing archaeological research in the twenty-first century. An important characteristic of computer-based techniques that sets them apart from all other approaches is their ability to deal with data sets that are too big and complex to handle by human minds. Therefore, they can be applied to all situations where we have 'big data'. GIS can deal with big data that also have a spatial dimension and in this way help to discern patterns and to simulate theories of human behaviour over large areas. It is therefore, in all probability, the next frontier for spatial technology in archaeology: to move beyond the boundaries of individual, site-based or micro-regional projects and to have a look at the 'big picture'.

\subsection{Spatial Analysis in Action}

In the following sections, I will introduce examples of the use of GIS-based spatial analysis that I believe illustrate current research trends, as well as its utility and limitations in practice. The main applications of GIS in archaeology can be classified into site location analysis, modelling movement and transport and visibility analysis, and I will provide examples of applications of all of them. In many cases these approaches are also used in conjunction-although we can suspect that this is partly because they are all available in the same toolbox and are therefore relatively easy to combine. Over the last few years, however, we can see that researchers are becoming more and more interested in coupling GIS to other techniques, such as social network analysis, advanced statistical methods and agent-based modelling.

\subsubsection{Site Location Analysis}

Without site location analysis, GIS might not have caught on as quickly as it did in archaeology. The earliest examples of GIS-based site location analysis can already be found in the early 1980s in the USA, and it is has never left the scene since then. At the time, it met a strongly felt need for more efficiently analysing site location preferences, a field of study which had received an enormous boost in the mid-1970s through site catchment analysis (Higgs and Vita-Finzi 1972; Findlow and Ericson 1980). The closely related practice of predictive modelling followed in its wake, responding to a demand from Cultural Resources Management to predict the distribution of archaeological remains in areas under threat of destruction (Kvamme 1983, 1984; Judge and Sebastian 1988). However, both methods quickly came under severe attack when post-processual theory made its way into archaeology in the late 1980s and early 1990s. To the post-processualists, site location analysis and predictive modelling were prime examples of how the processualists had chosen to ignore the human dimension in the study of the past. 
The first and foremost of these criticisms was the accusation of environmental determinism. The comparison of site locations to various environmental characteristics (such as soil type, slope or distance to natural resources) will inevitably favour environmental-deterministic explanations of site location patterns (Wheatley 1993, 1996, 2004; Gaffney and van Leusen 1995). In fact, it was argued that the use of GIS even forced the interpretation of site location patterns towards this point of view, since it could not handle 'soft' social and cognitive parameters and nonenvironmental data sets were scarce or unavailable. And even when the method can hardly be blamed for lack of data or for flawed archaeological-theoretical perspectives on site location, in practice it has proved to be very difficult to deal with non-environmental variables in site location analysis, although some real progress has been made in this respect over the last decade (Whitley et al. 2010; Verhagen et al. 2013a, 2016), also using, e.g. point pattern analysis (Bevan and Conolly 2006) and network analysis techniques (Bevan and Wilson 2013).

A second criticism of site location analysis is directed towards its quantitative nature: the results of site location analysis are typically presented as statistical tables and diagrams and offer the perspective of extrapolating the analysis results to other areas in the form of predictive maps - and they are therefore potentially misleading if the data and/or theories used are flawed (Wheatley 2004). In the early days, many GIS practitioners were well aware of the pitfalls of using and interpreting statistical analyses (see, e.g. Judge and Sebastian 1988). However, the backlash against quantitative methods in the early 1990s led to a general distrust in the use of statistics and a loss of proficiency amongst archaeologists that is still evident in university curricula these days. More importantly, dealing with field survey data for site location analysis has proved to be one of the trickier statistical issues in archaeology, since we usually have little control over the representativeness of sampling, and there are no established procedures for dealing with uneven representation (see, e.g. Orton 2000; Verhagen 2007: 115-168).
Thirdly, site location analysis and predictive modelling have been criticized for being static, and not taking into account the temporal dimension of human behaviour. Again, this is much more a question of the availability of suitable data rather than of flawed methodologytemporal dynamics of site location patterns can only be studied fruitfully if we have sufficiently reliable dating of archaeological sites and if we have sufficiently detailed palaeogeographical reconstructions.

At a deeper level, this debate shows the everlasting struggle between the application and development of scientific theory. We cannot expect a method or technique to operate in a theory-neutral environment; our choice of research questions, study regions, methods and data sets is governed by what we think we know about the past and by what we think we need to do to expand our knowledge. So if we really did not think that the environment influences site location choice, then we would never choose to analyse it. And on the other hand, patterns that suggest themselves to us, for example, while performing site location analysis, will find their way back into existing theoretical frameworks and either reinforce or challenge established opinions.

Basically, we are still looking for answers to the question of what made people settle where at a particular point in time. For this, site location analysis is not the only possible tool, but it remains a versatile, powerful and relatively straightforward way to explore site location preferences over large areas, to detect patterns and anomalies in settlement distribution, to compare these between areas and time periods and to place these in perspective together with other sources of information.

\subsubsection{Example: Long-Term Settlement Pattern Dynamics in the South of France}

Over the past 25 years, French scholars have worked extensively on collecting and analysing a large set of archaeological and environmental 
data in the southeast of France, in various study areas located along the river Rhône south of Valence and in the Provence and Languedoc regions on the Mediterranean coast. In the mid-1990s, considerable efforts were made within the Archaeomedes Project (DurandDastès et al. 1998; Van der Leeuw et al. 2003) to develop a protocol for site location analysis that could be applied to all study regions and that would allow to make long-term and crossregional comparisons of location preferences of rural settlement in the period from $800 \mathrm{BC}$ to $800 \mathrm{AD}$. This protocol was based on three important principles:

- The establishment of a standardized hierarchical classification of archaeological settlements

- The selection of a reduced number of relevant environmental variables for analysis that could be standardized for all regions

- The analysis of not just the location of the site itself but also its immediate surroundings

The results of the site location analysis clearly showed how the rhythms of occupation and abandonment of settlement changed between study areas and over the southeast of France as a whole. This pointed to a different story for in particular the Late Roman 'agricultural crisis' than was previously assumed. Instead of a political and economic crisis coupled to land abandonment and environmental degradation, it reflects a process of restructuration and stabilization of the settlement pattern, in which settlement is contracting into fewer locations, but not necessarily exploiting smaller areas (Favory et al. 1999; Fovet 2005).

At the time, performing the necessary calculations was a considerable task. The method however proved successful enough to be repeated in various other areas in France during the Archaedyn Project (Gandini et al. 2012), with similar outcomes. Invariably, the site location analyses showed a different story of occupation pattern dynamics than was previously assumed on the basis of local studies. However, the analysis was limited to a comparison of environmental preferences. Verhagen et al. (2013a, 2016) therefore decided to extend the analysis protocol of site location preferences to include non-environmental factors. For this, a distinction was made between what might be called 'socioenvironmental' variables, in particular accessibility and visibility, and 'true' socio-cultural variables. These include the influence of longterm occupation ('memory of landscape') on site location preference and the position of settlements in networks.

Modelling of accessibility through so-called cumulative cost paths (Verhagen et al. 2013a) was somewhat inconclusive, with little discernible direct influence on site location patterns. The importance of 'memory of landscape' for new occupation, however, was clearly demonstrated in two study regions in the south of France (Verhagen et al. 2016; Fig. 2.1). These results show that it is possible and desirable to include more sophisticated and archaeologically informed parameters into site location analysis, especially when environmental factors are not very good predictors.

\subsubsection{Modelling Movement and Transport}

One of the techniques offered by GIS that has attracted much interest in archaeology is leastcost path analysis (see, e.g. Bell and Lock 2000; Llobera 2000; Bell et al. 2002; Fábrega-Álvarez and Parcero-Oubiña 2007; Zakšek et al. 2008; Murrieta-Flores 2014). It is a method to find the optimal path between two or more locations. In a landscape that is characterized by differential accessibility, finding the most efficient route is a non-trivial task that requires determining the trade-off between distance travelled and obstacles on the route. These obstacles can be of a physical nature, like steep slopes, water bodies or vegetation hindering free movement, thus making detours potentially more attractive than taking the straight line. But we can also think of obstacles of a social nature, such as the presence of enemies, toll roads or even taboos on entering certain areas. And in some cases, intermediate locations may need to be visited in order 
Fig. 2.1 Land use heritage map of the Argens-Maures region (Var, Provence, France) for the first century AD, with archaeological sites. 'Existing settlements' are locations already occupied in the first century $\mathrm{BC}$, with continuing occupation in the first century AD. Source: Verhagen et al. (2016)

\section{Argens-Maures - reclassed heritage map 1st c. AD}

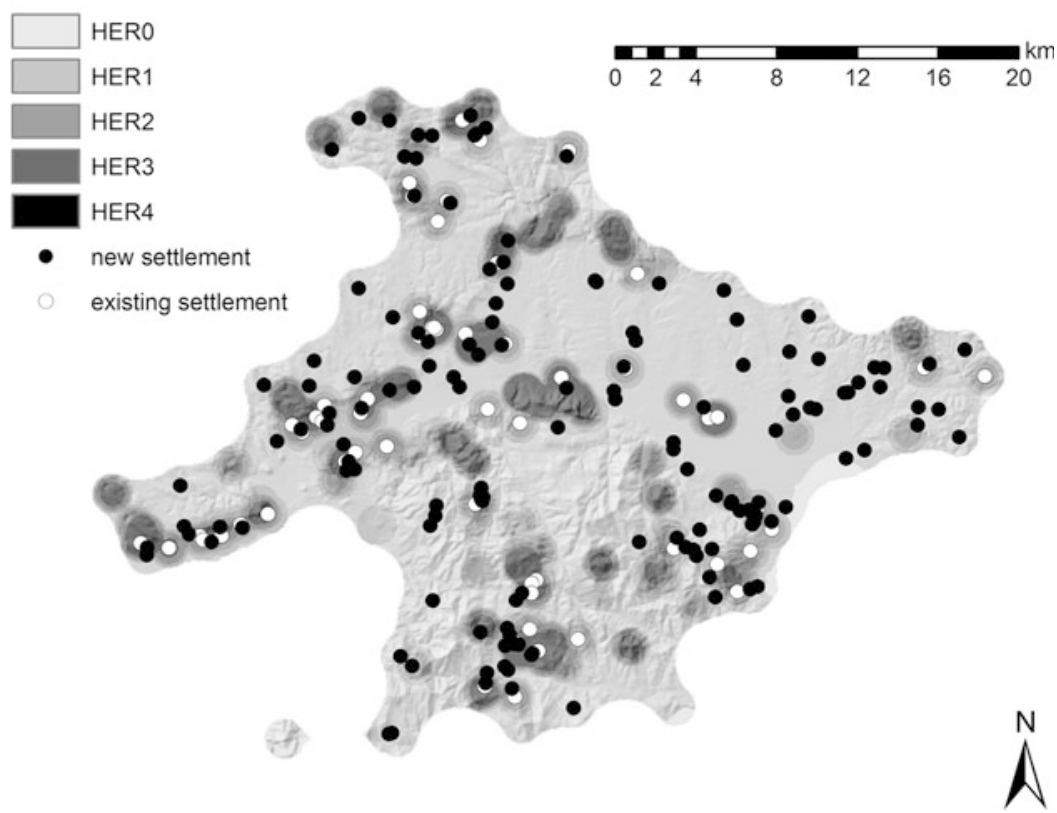

to go from A to $\mathrm{B}$, for example, because there is water, food, firewood and/or shelter available.

Tools for finding the most efficient route are implemented in all GIS software. First, a cost surface is defined that determines the costs of crossing one grid cell, usually specified in time or energy units spent. Slope is amongst the most common cost factors considered, and a number of methods have been developed to determine movement costs associated with slope (Herzog 2013). Different types of costs (monetary, social) could be included as well, but this will make things more complicated since we then cannot use the same cost units anymore. An accumulated cost surface is then created from a starting point, using Dijkstra's (1959) algorithm or one of its variants, which will provide the cost distance from the starting point to every grid cell in the study area. Finally, we can then determine the least-cost path between the starting location and any other location, giving us some idea on where transport and movement may have taken place (see, e.g. Van Leusen 2002: 308-329; Howey 2007; Zakšek et al. 2008). The accumulated cost surface can also be used to find the area that can be reached within a certain amount of time (or by spending a maximum amount of energy). This is often used to analyse the size, location and environmental characteristics of site territories (see, e.g. Robb and Van Hove 2003; Ducke and Kroefges 2008; Whitley et al. 2010). Alternatively, we can also determine cost surfaces calculated from all locations on a raster map and combine these into what has been called a total accessibility map or potential path field (Llobera 2000; Mlekuž 2014). These can be used to analyse the relative accessibility of a certain location.

The definition of the cost surfaces is seen as the main obstacle in least-cost path modelling. Even in the simplest case, when we only take into account the effect of slope on movement speed, there are a number of complex issues to be dealt with, including the accuracy and level of detail of the digital elevation models used (see Llobera 2000; Ejstrud 2005; Zakšek et al. 2008; Gietl et al. 2008; Herzog 2013), potential changes in topography since prehistory and the ability of 
humans to overcome topographical constraints by using technological solutions, such as paving or building bridges. Furthermore, different modes of transport can lead to different optimal paths: carts carrying heavy loads will have more difficulty negotiating steep slopes (see, e.g. Bevan 2013). And lastly, route networks will develop dynamically, depending on the already existing route and settlement networks in the region and period of study (Fovet and Zakšek 2014). The optimal path in such a situation may not be the one that takes least time or energy, but one that (also) uses the existing infrastructure.

In practice, therefore, least-cost path analyses have only been moderately successful in reconstructing past routes and movement (see, e.g. Bell and Lock 2000; Becker and Altschul 2008; Fiz and Orengo 2008; Verhagen and Jeneson 2012). Furthermore, validation of the models will be problematic in most cases since most prehistoric roads are difficult to detect-if they have survived at all. Mixed results have been reported as well by researchers who modelled 'natural' travel corridors as variables for site location analysis (Whitley and Hicks 2003; Whitley and Burns 2008; Murrieta-Flores 2012; Standley 2015; Van Lanen et al. 2015). This would lead us to suspect that 'natural' accessibility is a more important factor for locating new routes, rather than for locating new settlements per se. The application of least-cost path modelling is therefore more fruitfully seen in the light of hypothesis development and testing of where people might have moved in the past and what factors may have been influencing movement and transport.

More recently, it is acknowledged that social network analysis (SNA) techniques can be helpful to better understand the interaction between settlements and other transport nodes and to analyse patterns of communication at the regional scale (Verhagen et al. 2013b; Fovet and Zakšek 2014). Thus far, however, combining SNA and LCP modelling is still a complex task, since existing SNA software solutions are not integrated with GIS.

\subsubsection{Example: Modelling Transport and Movement in the Dutch Roman Limes}

In a recent paper, Groenhuijzen and Verhagen (2015) present a method to combine LCP and SNA in an attempt to model local transport and movement in the Dutch part of the Roman limes (the border of the Roman Empire). The Kromme Rijn study area is located on the south bank of the river Rhine, where differential accessibility is mainly due to differences in wetness: the low-lying floodplains are more prone to flooding than the levees, and thus movement is spatially constrained by the location of palaeo-channels in the area. By combining data from physiological experiments and specifying different costs for different modes of transport (on foot-unburdened and burdened - and by mule cart), it was possible to create LCP models connecting all Roman settlements in the area for different modes of transport and for different time slices, departing from a detailed palaeo-geographical reconstruction and a comprehensive site database. Since the focus was on local transport, the connections between settlements were only taken into account if they were less than $20 \mathrm{~min}$ travelling (approximately $1.5 \mathrm{~km}$ ) apart.

The modelled networks indicate a strong preference for movement on the levees (as expected) and show different patterns for different modes of transport. This is especially clear when SNA is used to analyse the importance of the connections. Betweenness centrality, which measures the number of times a node has to be passed in order to go from one place to another, is a good indicator of the importance of a node in a transport network (Fig. 2.2).

The analysis results indicate that the sites showing signs of higher status (as derived from the presence of stone building remains) are relatively well connected, which might indicate that their position in the network may have contributed to them becoming more important during the Roman period. It is also noteworthy that the network configuration, as well as the importance of settlements, changes with different 


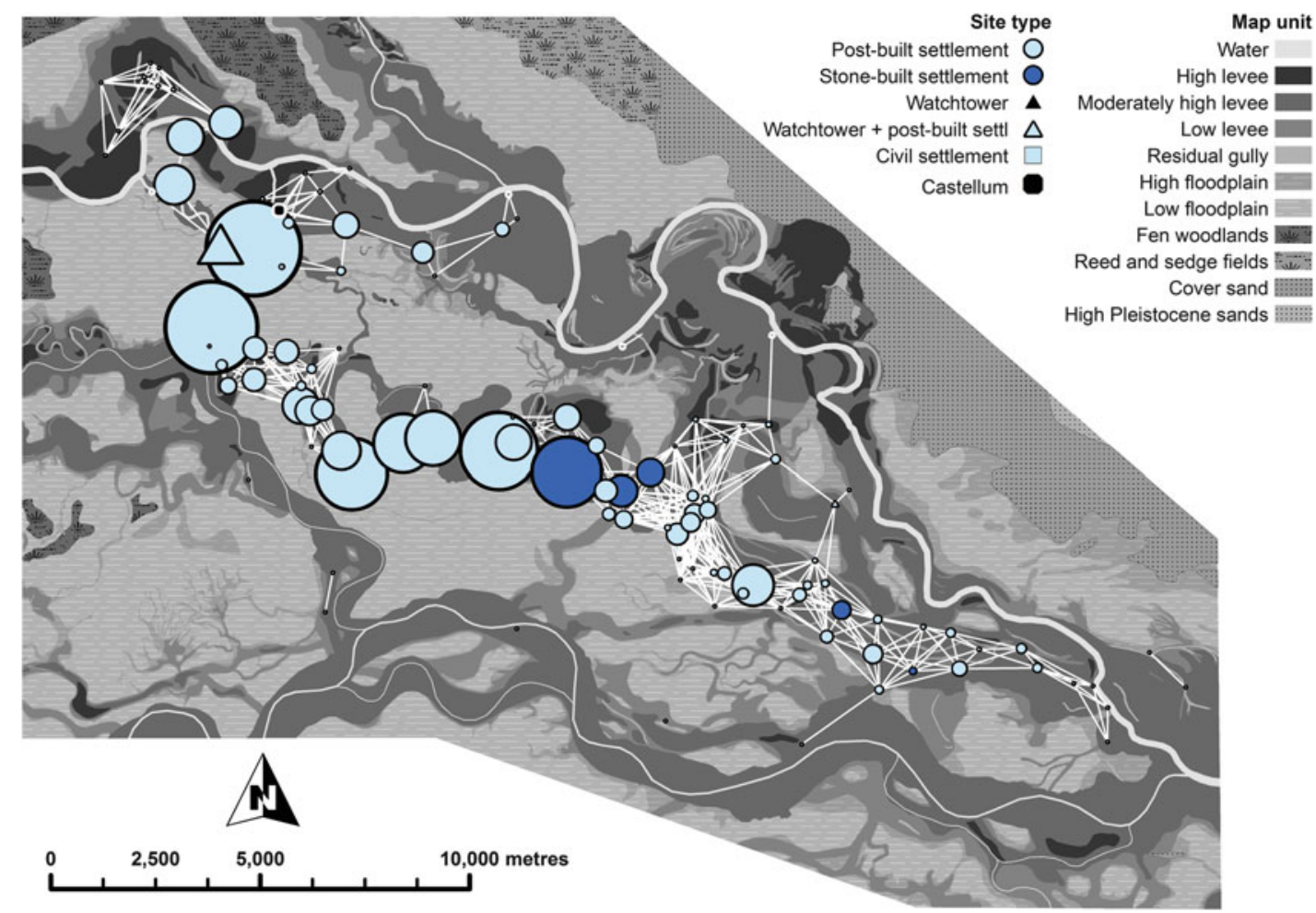

Fig. 2.2 Betweenness centrality measurements of Early Roman sites in the Kromme Rijn area, the Netherlands, based on least-cost paths calculated for mule cart transport. Source: Groenhuijzen and Verhagen (2015)

modes of transport, since the options for mule cart transport are much more limited than for movement on foot.

Furthermore, the military limes road, located close to the Rhine, and which has been the subject of most research on transport in the Dutch limes, is not very important as a connection between settlement sites. Obviously, this road did serve to connect the castella on the Rhine, but the lack of settlements on the Rhine banks means that it may not have been used frequently for local transport; the castella and adjoining vici were therefore peripheral to the local transport network.

\subsubsection{Visibility Analysis}

The third major branch of GIS methods that made its way into archaeology is the calculation of lines of sight and viewsheds. It is a technique that originated outside archaeology, where it is used in particular for siting military and telecommunications facilities. Archaeology however is quite unique in how it has used visibility analysis - and it is probably the nearest that GIS can come to representing bodily experience, by determining what places and objects can be seen from a particular vantage point (Tschan et al. 2000; Llobera 2003; Fitzjohn 2007).

In essence, visibility analysis starts by determining the line of sight between two locations, by comparing the elevation of location $A$ to the elevations encountered on a straight line to location B. If there is no higher elevation obstructing the view, then B can be seen from A. In this way, it is possible to calculate, for each and every grid cell in a region, which cells within a certain neighbourhood can be seen: this is the cell's viewshed. These viewsheds can then be combined to obtain cumulative (Wheatley 1995) or even total viewsheds (see Llobera 2003), which 
show the number of cells from which a location can be seen. Importantly, these viewsheds not only provide information on which locations are most visible but also on those which are hidden from view. Obviously, viewsheds can be calculated for different ranges of view (Wheatley and Gillings 2000; Llobera 2007a), and in this way multiple measures of visibility can be obtained to characterize landscapes and site locations.

Llobera (2003) introduced the concept of visualscape as ' $a$ spatial representation of $a$ visual property generated by or associated with a spatial configuration'. Using this concept, Llobera explicitly linked visual prominence and exposure to movement, which both are strongly connected to sensory perception. In practice, however, the application of GIS-based visibility analysis to questions of human perception of the landscape has not become very popular, despite several attempts in this direction (e.g. Llobera 1996; Trifković 2006; Gillings 2009; Lock et al. 2014). 3D modelling and virtual reality approaches would now seem to be more effective tools for this, although these generally lack the analytical capabilities offered by GIS.

Viewshed analysis has been applied more regularly and successfully in conjunction with site location analysis (e.g. Sevenant and Antrop 2007; De Montis and Caschili 2012) as well as with least-cost path modelling (e.g. MurrietaFlores 2014; Lock et al. 2014), not just to test whether visibility may have been a factor influencing site location but more importantly to understand how archaeological sites are visually related. This has been especially of interest for analysing the placement of megalithic monuments, burial mounds, hillforts, castles and other monumental and defensive sites (e.g. Gaffney and Stančič 1991; Wheatley 1995; Ruggles and Medyckyj-Scott 1996; Loots et al. 1999; Lake and Woodman 2003; Bourgeois 2013: 105-158; Čučković 2015).

However, it is also a technique that is fraught with difficulties, since its results highly depend on the quality of the digital elevation models used, both in terms of vertical accuracy (Fisher 1992; Loots et al. 1999; Ruestes Bitrià 2007) and in terms of how well a DEM, which is stripped of vegetation, represents a prehistoric landscape (Llobera 2007b). Viewshed analysis is also highly sensitive to edge effects and can therefore only be applied to large areas, which even today might lead to problems with computing power. Furthermore, the question of what specific elements in the landscape would be important to see is not always addressed, resulting in maps of cumulative viewsheds that only provide information on the proportion of the landscape that is visible from a vantage point. Even though there has been some research done on the level of detail of objects that can be discerned at various distances (e.g. Ogburn 2006), GIS would not seem the best suited tool for this, and many studies interested in understanding visibility of objects, especially in built-up spaces, now tend to use 3D modelling instead.

\subsubsection{Example: Studying Visibility and Movement in the Sierra Morena}

An exemplary case study that combined visibility analysis, path modelling and site location analysis was presented by Murrieta-Flores (2012, 2014). It is a good example of how to use all three analysis techniques together in an attempt to better understand the development of settlement patterns and the placement of megalithic monuments in the western Sierra Morena (Southwestern Spain). It was long suspected that megalithic monuments in Iberia are linked to potential patterns of movement and might have been used as navigational markers, associated with a long tradition of transhumance. In order to test this hypothesis, Murrieta-Flores first modelled potential pathways of movement in the study region and then analysed the visual characteristics of the megalithic monuments in order to see whether they were located in places where they could be seen and would be dominating the view.

Least-cost paths were created originating from mountain passes at the edge of the study area and crossing the whole area (MurrietaFlores 2012) — a technique similar to the one used by Whitley and Hicks (2003). The density 


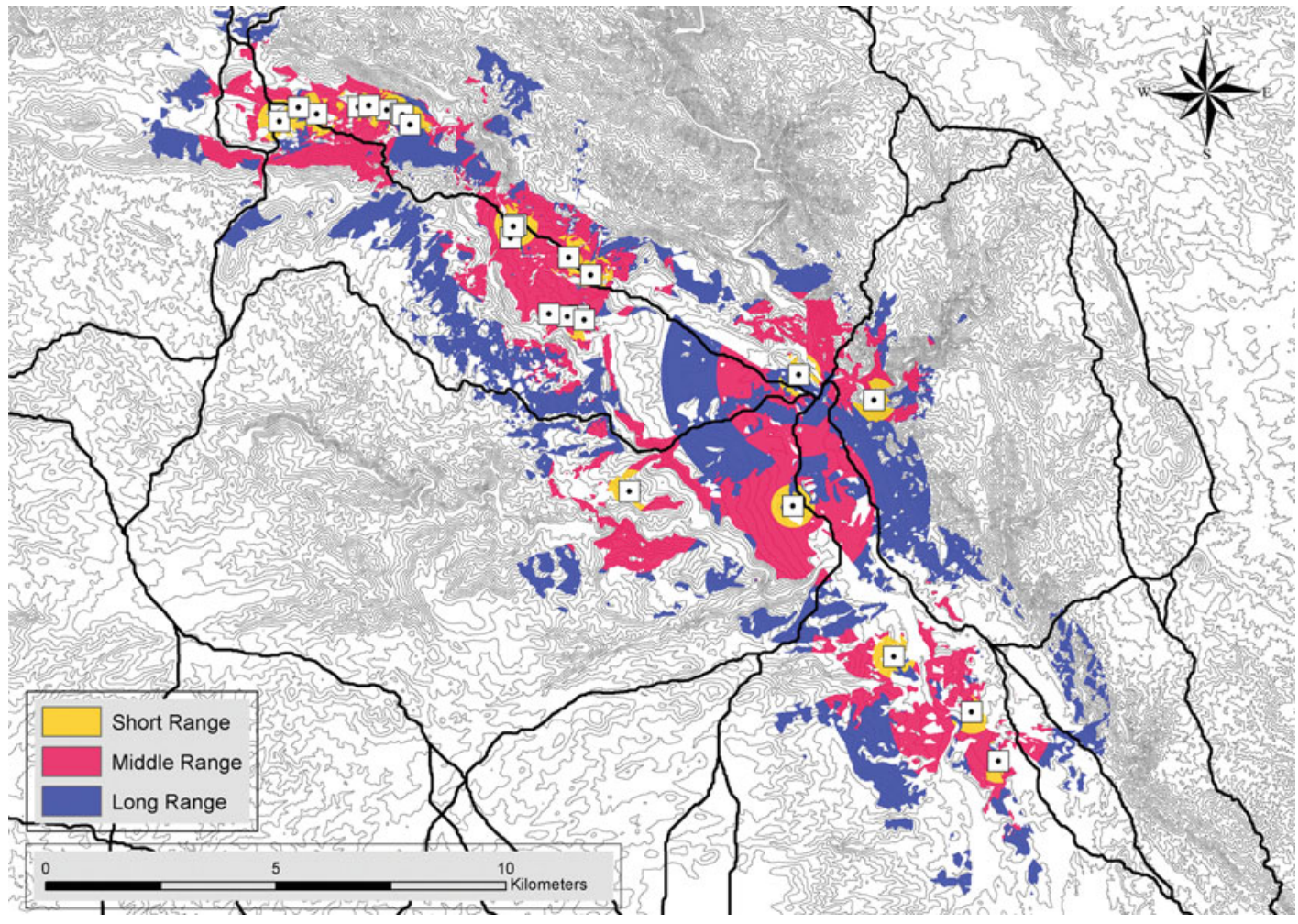

Fig. 2.3 Visual ranges of megaliths along the Viar Valley (Sierra Morena, Andalusia, Spain) and their correspondence with natural corridors. Source: Murrieta-Flores (2014)

of least-cost paths was then used to generate 'natural movement corridors', that were interpreted as potential routes used for the movement of people and cattle in the annual transhumance orbit. These corridors were shown to have a statistically significant relationship with the placement of settlements in the Copper and Bronze Age. It also became clear that most of the megalithic monuments were located quite close to the modelled corridors (Fig. 2.3).

By then creating viewsheds for each of the megalithic monuments, and looking at the direction of view, it proved possible to show that the monuments were in places where they could oversee relatively long stretches of the corridors, considerably longer than from other points in the landscape (Murrieta-Flores 2014). However, it seems less likely that they have acted as navigational markers-intermediate waypoints would have been necessary for effective wayfinding. This would point to a more symbolic role for the monuments, for example, in maintaining collective memory.

\subsection{Moving into New Territories}

In the preceding sections, I have described existing trends in GIS-based spatial analysis with GIS in archaeology. The methods and approaches outlined are well developed, even when in some cases there are still some technical issues to be solved, for example, where it concerns the best ways to calculate least-cost paths. The more important questions to be tackled, however, are related to the archaeologicaltheoretical perspective on spatial analysis and to the increasing cross-fertilization between GIS and other digital techniques.

Despite the widespread use of GIS in archaeological practice nowadays, archaeologicaltheoretical thinking still has to come to terms 
with the idea of using formalized spatial analysis as a primary line of attack to better understand the regional and diachronic dynamics of settlement and land use. The emphasis placed by postprocessual theoreticians on narrative, at the expense of scientific methods, has led to a rift between 'science-based' and mainstream archaeology that is still very evident today. It has also led to an attitude amongst archaeologists of seeing 'hard science' methods and techniques as auxiliary tools that provide helpful data to be used in the construction of an historical narrative, rather than as a possible focus of archaeological research. For this reason, 'digital archaeology' is still mainly the realm of specialists, and developing and diffusing digital tools and models for specific archaeological purposes is often a low priority. It is, in my view, a form of shortsightedness that will be detrimental to the discipline in the long run, since, as pointed out earlier, computer techniques allow us to analyse data and construct models that go far beyond the capacity of the human brain and are therefore essential to push the boundaries of our knowledge of the past. They are also extremely well suited for formalizing hypotheses and testing these, thereby fulfilling an important role as heuristic devices, as tools that help us to think more deeply about our assumptions. But if we don't consider the tools themselves as an object of inquiry, it will only lead us to be dependent on what expertsoften from different disciplines-develop, instead of setting our own agenda for digital archaeology.

Users of GIS in archaeology should be aware of this and keep an open eye for developing new tools and for combining spatial analysis with other approaches. As mentioned, network analysis is gaining in importance and will become much better integrated with GIS in the near future. A similar development can be observed where it concerns the combination of GIS and dynamical simulation modelling, which is a rapidly growing field of archaeological research as well (Kohler and Van der Leeuw 2007; Wurzer et al. 2015). The amalgamation of GIS-based analysis techniques into agent-based modelling and advanced statistical software is already on its way and will lead to a further integration and extension of spatial analysis techniques. Perhaps the term GIS will not be that relevant anymore in a decade or so, and the acronym will change meaning to Geographical Information Science.

Furthermore, it would be useless to develop tools and models without taking into account the realities of archaeological data, especially when we are thinking of tackling questions at the supra-regional level. The assessment of the reliability of archaeological and to a lesser extent environmental data sets is probably the most neglected factor in current studies. Archaeology does not qualify as a field with really big data, but it has lots of 'messy' data coming from a multitude of sources with distinct regional and historical peculiarities-one might say that archaeological data has 'character' (Cooper and Green 2015). Obviously, this makes setting up standardized analysis protocols challenging and forces us to be very critical not only of the original data but also of the modelling results produced, since errors in the data will be propagated into our analyses. Tools to perform effective data mining on digital archaeological data are still in their infancy, but will inevitably start to play a more important role in future research aiming at the analysis of data from multiple sources across institutional and even national boundaries (Wilcke 2015; Chiarcos et al. 2016).

GIS will certainly continue to contribute to the debate on the utility of digital and quantitative methods in archaeology — and we need to be aware that it has clear limitations in what it can do for us. In the end, it is the eclectic attitude advocated by Hacıgüzeller (2012) that will bring us further: concepts from GIS need to be combined with other theoretical and methodological approaches to create a new practice of archaeology-one in which doing spatial analysis is as natural as analysing pottery, interpreting stratigraphy or theorizing about identity and in which all these aspects of doing archaeology will be mutually reinforcing. 


\section{References}

Becker KM, Altschul JH (2008) Path finding: the archaeology of trails and trail systems. In: Altschul JH, Rankin AG (eds) Fragile patterns: the archaeology of the western Papaguería. SRI Press, Tucson, pp 419-446

Bell T, Lock G (2000) Topographic and cultural influences on walking the Ridgeway in later prehistoric times. In: Lock G (ed) Beyond the map. Archaeology and spatial technologies. IOS Press, Amsterdam, pp 85-100

Bell T, Wilson A, Wickham A (2002) Tracking the Samnites: landscape and communications routes in the Sangro Valley, Italy. Am J Archaeol 106:169-186

Bevan A (2013) Travel and interaction in the Greek and Roman world. A review of some computational modelling approaches. In: Dunn S, Mahoney S (eds) The digital classicist 2013. Wiley-Blackwell, London

Bevan A, Conolly J (2006) Multiscalar approaches to settlement analysis. In: Lock G, Molyneaux BL (eds) Confronting scale in archaeology. Issues of theory and practice. Springer, New York, pp 217-324

Bevan A, Wilson A (2013) Models of settlement hierarchy based on partial evidence. J Archaeol Sci 40:2415-2427

Bourgeois Q (2013) Monuments on the horizon. The formation of the barrow landscape throughout the 3rd and 2nd millennium BC. Sidestone Press, Leiden

Chiarcos C, Lang M, Verhagen P (2016) IT-assisted exploration of excavation reports using natural language processing in the archaeological research process. In: Campana S, Scopigno R, Carpentiero G, Cirillo M (eds) CAA 2015. Keep the revolution going. Proceedings of the 43rd annual conference on computer applications and quantitative methods in Archaeology, Siena. Archaeopress, Oxford, pp 87-94

Cooper A, Green C (2015) Embracing the complexities of 'big data' in archaeology: the case of the English Landscape and Identities project. J Archaeol Method Theory 23(1):271-304. https://doi.org/10.1007/ s10816-015-9240-4

Čučković Z (2015) Exploring intervisibility networks: a case study from Bronze and Iron Age Istria (Croatia and Slovenia). In: Giligny F, Djindjian F, Costa L, Moscati P, Robert S (eds) CAA2014. 21st century archaeology. Concepts, methods and tools. Proceedings of the 42nd annual conference on computer applications and quantitative methods in archaeology. Archaeopress, Oxford, pp 469-478

De Montis A, Caschili S (2012) Nuraghes and landscape planning: coupling viewshed with complex network analysis. Landsc Urban Plan 105:315-324

Dijkstra E (1959) A note on two problems in connexion with graphs. Numer Math 1:269-271

Ducke B, Kroefges PC (2008) From points to areas: constructing territories from archaeological site patterns using an enhanced Xtent model. In: Posluschny A, Lambers K, Herzog I (eds) Layers of perception. 35th International conference on computer applications and quantitative methods in archaeology (CAA), April 2007, Berlin, Germany. Dr. Rudolf Habelt GmbH, Bonn, pp 245-251

Durand-Dastès F, Favory F, Fiches JL, Mathian H, Pumain D, Raynaud C, Sanders L, van der Leeuw S (1998) Des oppida aux métropoles. Archéologues et géographes en vallée du Rhône. Anthropos, Paris

Ejstrud B (2005) Cost surface analysis and ancient roads: a comparison. In: Berger JF, Bertoncello F, Braemer F, Davtian G, Gazenbeek M (eds) Temps et espaces de l'Homme en société, analyses et modèles spatiaux en archéologie, Actes des XXVe Rencontres internationales d'archéologie et d'histoire d'Antibes, 21-23 Octobre 2004. Éditions APDCA, SophiaAntipolis, pp 135-139

Fábrega-Álvarez P, Parcero-Oubiña C (2007) Proposals for an archaeological analysis of pathways and movement. Archeologia e Calcolatori 18:121-140

Favory F, Girardot JJ, Nuninger L, Tourneux FP (1999) Archaeomedes II: une étude de la dynamique de l'habitat rural en France méridionale, dans la longue durée (800 av. J.-C. - 1600 ap. J.-C.) AGER 9:15-35

Findlow FJ, Ericson JE (eds) (1980) Catchment analysis. Essays on prehistoric resource space. University of California, Los Angeles

Fisher PF (1992) First experiments in viewshed uncertainty: simulating the fuzzy viewshed. Photogramm Eng Remote Sens 58:345-352

Fitzjohn M (2007) Viewing places: GIS applications for examining the perception of space in the mountains of Sicily. World Archaeol 39:36-50

Fiz I, Orengo H (2008) Simulating communication routes in mediterranean alluvial plains. In: Posluschny A, Lambers K, Herzog I (eds) Layers of perception. 35 th International conference on computer applications and quantitative methods in archaeology (CAA), April 2007, Berlin, Germany. Dr. Rudolf Habelt GmbH, Bonn, pp 316-321

Fleming A (2006) Post-processual landscape archaeology: a critique. Camb Archaeol J 16:267-280

Fovet E (2005) Dynamique spatiale du peuplement et analyse des ressources agro-pastorales dans le bassin de Combas et le vallon de l'Aigalade (Gard, France), du Bronze final au bas Moyen Age. In: Berger JF, Bertoncello F, Braemer F, Davtian G, Gazenbeek M (eds) Temps et espaces de l'Homme en société, analyses et modèles spatiaux en archéologie. Actes des XXVe Rencontres internationales d'archéologie et d'histoire d'Antibes, 21-23 Octobre 2004. Éditions APDCA, Sophia-Antipolis, pp 499-503

Fovet E, Zakšek K (2014) Path network modelling and network of aggregated settlements: a case study in Languedoc (southeastern France). In: Polla S, Verhagen P (eds) Computational approaches to movement in archaeology. Theory, practice and interpretation of factors and effects of long term landscape formation and transformation. De Gruyter, Berlin, pp $43-72$ 
Gaffney V, Stančič Z (1991) GIS approaches to regional analysis: a case study of the island of Hvar. Znanstveni institut Filozofske fakultete, Ljubljana

Gaffney V, van Leusen M (1995) Postscript-GIS, environmental determinism and archaeology: a parallel text. In: Lock G, Stančič Z (eds) Archaeology and geographical information systems: a European perspective. Taylor and Francis, London, pp 367-382

Gandini C, Favory F, Nuninger L (eds) (2012) Settlement patterns, production and trades from the Neolithic to the Middle Ages, ARCHAEDYN, Seven millennia of territorial dynamics, final conference, Dijon, 23-25 June 2008. Archaeopress, Oxford

Gietl R, Doneus M, Fera M (2008) Cost distance analysis in an alpine environment: comparison of different cost surface modules. In: Posluschny A, Lambers K, Herzog I (eds) Layers of perception. 35th International conference on computer applications and quantitative methods in archaeology (CAA), April 2007, Berlin, Germany. Dr. Rudolf Habelt GmbH, Bonn, p 342 \& CD-ROM

Gillings M (2009) Visual affordance, landscapes and the megaliths of Alderney. Oxf J Archaeol 28:335-356

Groenhuijzen MR, Verhagen P (2015) Exploring the dynamics of transport in the Dutch limes. eTopoi $\mathrm{J}$ Anc Stud Spec 4:25-47

Hacıgüzeller P (2012) GIS, critique, representation and beyond. J Soc Archaeol 12:245-263

Hasenstab RJ (1983) A preliminary cultural resource sensitivity analysis for flood control facilities construction in the Passaic River basin of New Jersey. US Army Corps of Engineers, Marietta, GA

Herzog I (2013) Theory and practice of cost functions. In: Contreras F, Farjas M, Melero FJ (eds) Fusion of cultures, Proceedings of the 38th annual conference on computer applications and quantitative methods in archaeology, Granada, Spain, April 2010. Archaeopress, Oxford, pp 375-382

Higgs ES, Vita-Finzi C (1972) Prehistoric economy: a territorial approach. In: Higgs ES (ed) Papers in economic prehistory. Studies by members and associates of the British Academy major research project in the early history of agriculture. Cambridge University Press, Cambridge, pp 27-36

Howey MCL (2007) Using multi-criteria cost surface analysis to explore past regional landscapes: a case study of ritual activity and social interaction in Michigan, AD 1200-1600. J Archaeol Sci 34:1830-1846

Huggett J (2013) Disciplinary issues: challenging the research and practice of computer applications in archaeology. In: Earl G, Sly T, Chrysanthi A, Murrieta-Flores P, Papadopoulos C, Romanowka I, Wheatley D (eds) Archaeology in the digital era. Papers from the 40th annual conference of computer applications and quantitative methods in archaeology (CAA), Southampton, 26-29 March, vol 2012. Amsterdam University Press, Amsterdam, pp 13-24
Judge JW, Sebastian L (eds) (1988) Quantifying the present and predicting the past: theory, method and application of archaeological predictive modelling. U.S. Department of the Interior, Bureau of Land Management, Denver

Kohler TA, van der Leeuw S (2007) Model-based archaeology of socionatural systems. School of Advanced Research, Santa Fe

Kvamme KL (1983) A manual for predictive site location models: examples from the Grand Junction District, Colorado. Bureau of Land Management, Grand Junction District

Kvamme KL (1984) Models of prehistoric site location near Pinyon Canyon, Colorado. In: Condie CJ (ed) Papers of the Philmont conference on the archaeology of northeastern New Mexico. New Mexico Archaeological Council, Albuquerque, pp 349-370

Kvamme KL (1999) Recent directions and developments in geographic information systems. J Archaeol Res 7:153-201

Lake M, Woodman PE (2003) Visibility studies in archaeology: a review and case study. Environ Plann B Plann Des 30:689-707

Llobera M (1996) Exploring the topography of mind: GIS, social space and archaeology. Antiquity 70:612-622

Llobera M (2000) Understanding movement: a pilot model towards the sociology of movement. In: Lock $G$ (ed) Beyond the map. Archaeology and spatial technologies. IOS Press, Amsterdam, pp 65-84

Llobera M (2003) Extending GIS-based visual analysis: the concept of visualscapes. Int J Geogr Inf Sci $17: 25-48$

Llobera M (2007a) Reconstructing visual landscapes. World Archaeol 39:51-69

Llobera M (2007b) Modeling visibility through vegetation. Int J Geogr Inf Sci 21:799-810

Lock G, Kormann M, Pouncett J (2014) Visibility and movement: towards a GIS-based integrated approach. In: Polla S, Verhagen $\mathrm{P}$ (eds) Computational approaches to movement in archaeology. Theory, practice and interpretation of factors and effects of long term landscape formation and transformation. De Gruyter, Berlin, pp 23-42

Loots L, Nackaerts K, Waelkens M (1999) Fuzzy viewshed analysis of the Hellenistic city defence system at Sagalassos, Turkey. In: Dingwall L, Exon S, Gaffney V, Laflin S, van Leusen M (eds) Archaeology in the age of the internet. CAA97. Computer applications and quantitative methods in archaeology. Proceedings of the 25th anniversary conference, University of Birmingham, April 1997. Archaeopress, Oxford, p 82 \& CD-ROM

McCoy MD, Ladefoged TN (2009) New developments in the use of spatial technology in archaeology. J Archaeol Res 17:263-295

Mlekuž D (2014) Exploring the topography of movement. In: Polla S, Verhagen $\mathrm{P}$ (eds) Computational approaches to movement in archaeology. Theory, 
practice and interpretation of factors and effects of long term landscape formation and transformation. De Gruyter, Berlin, pp 5-22

Murrieta-Flores P (2012) Understanding movement during late prehistory through spatial technologies: the role of natural areas of transit in south-western Iberia. Trab Prehist 69:114-133

Murrieta-Flores P (2014) Developing computational approaches for the study of movement: assessing the role of visibility and landscape markers in terrestrial navigation during Iberian late prehistory. In: Polla S, Verhagen P (eds) Computational approaches to movement in archaeology. Theory, practice and interpretation of factors and effects of long term landscape formation and transformation. De Gruyter, Berlin, pp 99-132

Ogburn DE (2006) Assessing the level of visibility of cultural objects in past landscapes. J Archaeol Sci 33:405-413

Orton C (2000) Sampling in archaeology. Cambridge University Press, Cambridge

Robb J, van Hove D (2003) Gardening, foraging and herding: neolithic land use and social territories in Southern Italy. Antiquity 77:241-254

Ruestes Bitrià C (2007) A multi-technique GIS visibility analysis for studying visual control of an Iron Age landscape. Internet Archaeology 23. 10.11141/ia.23.4

Ruggles CLN, Medyckyj-Scot DJ (1996) Site location, landscape visibility, and symbolic astronomy: a Scottish case study. In: Maschner HDG (ed) New methods, old problems: geographic information systems in modern archaeological research. Southern Illinois University, Carbondale, IL, pp 127-146

Sevenant M, Antrop M (2007) Settlement models, land use and visibility in rural landscapes: two case studies in Greece. Landsc Urban Plan 80:362-374

Standley A (2015) Making tracks: simulating prehistoric human travel networks. Northland, New Zealand. Vrije Universiteit Amsterdam, Amsterdam

Thomas J (1993) The politics of vision and the archaeologies of landscape. In: Bender B (ed) Landscape, politics and perspectives. Berg, Oxford, pp 19-48

Thomas J (2001) Archaeologies of place and landscape. In: Hodder I (ed) Archaeological theory today. Polity Press, Cambridge, pp 165-186

Thomas J (2004) Archaeology and modernity. Routledge, London

Tilley C (2004) The materiality of stone: explorations in landscape phenomenology 1 . Berg, Oxford

Tilley C (2008) Body and image: explorations in landscape phenomenology 2. Left Coast Press, Walnut Creek, CA

Trifković V (2006) Persons and landscapes: shifting scales of landscape archaeology. In: Lock G, Molyneaux BL (eds) Confronting scale in archaeology. Issues of theory and practice. Springer, New York, pp 217-324

Tschan AP, Raczkowski W, Latalowa M (2000) Perception and viewshed: are they mutually inclusive? In:
Lock G (ed) Beyond the map. Archaeology and spatial technologies. IOS Press, Amsterdam, pp 28-48

van der Leeuw S, Favory F, Fiches JL (eds) (2003) Archéologie et systèmes socio-environnementaux. Études multiscalaires sur la vallée du Rhône dans le programme Archaeomedes. CNRS Éditions, Paris

van Lanen R, Kosian MC, Groenewoudt BJ, Spek T, Jansma E (2015) Best travel options: modelling Roman and early-medieval routes in the Netherlands using a multi-proxy approach. J Archaeol Sci Rep 3:144-159

van Leusen PM (2002) Pattern to process. Methodological investigations into the formation and interpretation of spatial patterns in archaeological landscapes. Rijksuniversiteit Groningen, Groningen

Verhagen P (2007) Case studies in archaeological predictive modelling. Leiden University Press, Leiden

Verhagen P (2012) Biting off more than we can chew? The current and future role of digital techniques in landscape archaeology. In: Kluiving SJ, GuttmanBond E (eds) Landscape archaeology between art and science. From a multi- to an interdisciplinary approach. Amsterdam University Press, Amsterdam, pp 309-320

Verhagen P, Jeneson K (2012) A Roman puzzle. Trying to find the Via Belgica with GIS. In: Chrysanthi A, Murrieta-Flores P, Papadopoulos C (eds) Thinking beyond the tool. Archaeological computing and the interpretive process. Archaeopress, Oxford, pp 123-130

Verhagen P, Whitley TG (2012) Integrating archaeological theory and predictive modeling. A live report from the scene. J Archaeol Method Theory 19:49-100

Verhagen P, Nuninger L, Tourneux FP, Bertoncello F, Jeneson K (2013a) Introducing the human factor in predictive modelling: a work in progress. In: Earl G, Sly T, Chrysanthi A, Murrieta-Flores P, Papadopoulos C, Romanowka I, Wheatley D (eds) Archaeology in the digital era. Papers from the 40th annual conference of computer applications and quantitative methods in archaeology (CAA), Southampton, 26-29 March 2012. Amsterdam University Press, Amsterdam, pp 379-388

Verhagen P, Brughmans T, Nuninger L, Bertoncello F (2013b) The long and winding road. Combining least cost paths and network analysis techniques for settlement location analysis and predictive modelling. In: Earl G, Sly T, Chrysanthi A, Murrieta-Flores P, Papadopoulos C, Romanowka I, Wheatley D (eds) Archaeology in the digital era. Papers from the 40th annual conference of computer applications and quantitative methods in archaeology (CAA), Southampton, 26-29 March 2012. Amsterdam University Press, Amsterdam, pp 357-366

Verhagen P, Nuninger L, Bertoncello F, Castrorao Barba A (2016) Estimating the "memory of landscape" to predict changes in archaeological settlement patterns. In: Campana S, Scopigno R, Carpentiero G, Cirillo M (eds) CAA 2015. Keep the revolution going. Proceedings of 
the 43rd annual conference on computer applications and quantitative methods in Archaeology, Siena. Archaeopress, Oxford, pp 623-636

Wagtendonk A, Verhagen P, Jeneson K, Soetens S, de Kleijn M (2009) Past in place: the role of geo-ICT in present-day archaeology. In: Scholten HJ, van de Velde R, van Manen N (eds) Geospatial technology and the role of location within science. Springer, Dordrecht, pp 59-86

Wheatley D (1993) Going over old ground: GIS, archaeological theory and the act of perception. In: Andresen J, Madsen T, Scollar I (eds) Computing the past. Computer applications and quantitative methods in archaeology. CAA92. Aarhus University Press, Aarhus, pp 133-138

Wheatley D (1995) Cumulative viewshed analysis: a GIS-based method for investigating intervisibility, and its archaeological application. In: Lock G, Stančič $\mathrm{Z}$ (eds) Archaeology and geographical information systems: a European perspective. Taylor and Francis, London, pp 171-185

Wheatley D (1996) Between the lines: the role of GIS-based predictive modelling in the interpretation of extensive survey data. Analecta Praehistorica Leidensia 28:275-292

Wheatley D (2004) Making space for an archaeology of place. Internet Archaeology 15. 10.11141/ia.15.10

Wheatley D, Gillings M (2000) Vision, perception and GIS: developing enriched approaches to the study of archaeological visibility. In: Lock G (ed) Beyond the map. Archaeology and spatial technologies. IOS Press, Amsterdam, pp 1-27
Whitley TG, Burns G (2008) Conditional GIS surfaces and their potential for archaeological predictive modelling. In: Posluschny A, Lambers K, Herzog I (eds) Layers of perception. 35th International conference on computer applications and quantitative methods in archaeology (CAA), April 2007, Berlin, Germany. Dr. Rudolf Habelt GmbH, Bonn, pp 292-298

Whitley TG, Hicks LM (2003) A geographic information systems approach to understanding potential prehistoric and historic travel corridors. Southeast Archaeol 22:77-91

Whitley TG, Moore G, Goel G, Jackson D (2010) Beyond the marsh: settlement choice, perception and spatial decision-making on the Georgia coastal plain. In: Frischer B, Crawford J, Kollers D (eds) CAA 2009. Making history interactive. Computer applications and quantitative methods in archaeology. Proceedings of the 37th conference, Williamsburg, VA, USA. Archaeopress, Oxford, pp 380-390

Wilcke WX (2015) ARIADNE D16.1: first report on data mining. VU University, Amsterdam

Wurzer G, Kowarik K, Reschreiter H (2015) Agent-based modeling and simulation in archaeology. Springer, Cham

Zakšek K, Fovet E, Nuninger L, Pobodnikar T (2008) Path modelling and settlement pattern. In: Posluschny A, Lambers K, Herzog I (eds) Layers of perception. 35th International conference on computer applications and quantitative methods in archaeology (CAA), April 2007, Berlin, Germany. Dr. Rudolf Habelt GmbH, Bonn, pp 309-315

Open Access This chapter is licensed under the terms of the Creative Commons Attribution 4.0 International License (http://creativecommons.org/licenses/by/4.0/), which permits use, sharing, adaptation, distribution and reproduction in any medium or format, as long as you give appropriate credit to the original author(s) and the source, provide a link to the Creative Commons license and indicate if changes were made.

The images or other third party material in this chapter are included in the chapter's Creative Commons license, unless indicated otherwise in a credit line to the material. If material is not included in the chapter's Creative Commons license and your intended use is not permitted by statutory regulation or exceeds the permitted use, you will need to obtain permission directly from the copyright holder. 